\title{
PENGARUH INFLUENCER MARKETING SEBAGAI STRATEGI PEMASARAN DIGITAL ERA MODEREN (SEBUAH STUDI LITERATUR)
}

\author{
Muhammad Zaki Rosyadi \\ Universitas Islam Negeri Sunan Ampel Surabaya \\ rosyadizaki9@gmail.com
}

\begin{abstract}
ABSTRAK
Salah satu faktor yang menjadi keberhasilan pemasaran melalui media sosial adalah dengan menggunakan influencer marketing Metodologi yang digunakan adalah pendekatan melalui studi literatur. penulis menggunakan sumber penelitian empiris dengan mengumpulkan data dan informasi yang berkaitan dengan pemasaran lewat media sosial dan pengaruh dari seorang influencer dalam memberikan informasi terhadap sebuah produk agar mencapai tujuan akhir yang ingin dicapai adalah dapat dengan signifikan meningkatkan penjualan dan menampilkan brand image perusahaan yang baik kepada konsumen.
\end{abstract}

Kata kunci : Media Sosial, Influencer Marketing, dan Pemasaran

\begin{abstract}
One of the factors which form the basis of the success of marketing via social media is by using influencer marketing.The methodology used is the approach through then a brilliant literary student. The use writers a source of empirical research by rounding up all of the data and information pertaining to marketing via social media and the influence of from a influencer in providing information on product gdp figures last week launched on an to achieve the goal of the end of which is trying to achieve is to be able to significantly increases the of a sale and the on the other hand displayed the image of companies brand
\end{abstract}

Key word : Social Media, Influencer Marketing, and Marketing 


\section{PENDAHULUAN}

Pemasaran adalah salah satu lini penting dalam bisnis, bagaimana sebuah produk diperkenalkan hingga didistribusikan hingga sampai pada tangan konsumen adalah salah satu tugas dari bagian pemasaran, saat ini terdapat banyak metode dan cara yang bisa digunakan untuk memasarkan suatu produk barang atau jasa, tetapi seiring dengan perkembangan zaman para pemasar pun harus mengubah pola dan strategi pemasaran supaya tetap mampu mengikuti perkembangan jaman dan mampu bersaing di pasar bebas dengan para pesaingnya, salah satunya adalah dengan memanfaatkan teknologi pemasaran digital untuk melengkapi taktik pemasaran konvensional yang telah ada.

Berbelanja secara online atau e-commerce telah menjadi salah satu gaya hidup dan kebiasaan masyarakat moderen, seperti data dari global e-retail yang mencatat pertumbuhan pemasaran di dunia yang mencapai 2.3 triliun U.S. dolar pada tahun 2017 dengan jumlah pertumbuhan terbesar ada di kawasan asia pasifik yang umumnya ada pada negara negara seperti Indonesia dan India, diikuti oleh Mexico dan China, pertumbuhan ini bisa dilihat melalui gambar 1 dimana grafik penjualan retail dari tahun 2015 - hingga perkiraan 2018 - 2021 mencapai pertumbuhan yang signifikan yaitu rata-rata kenaikan antara $1 \%-3 \%$ setiap tahunnya.

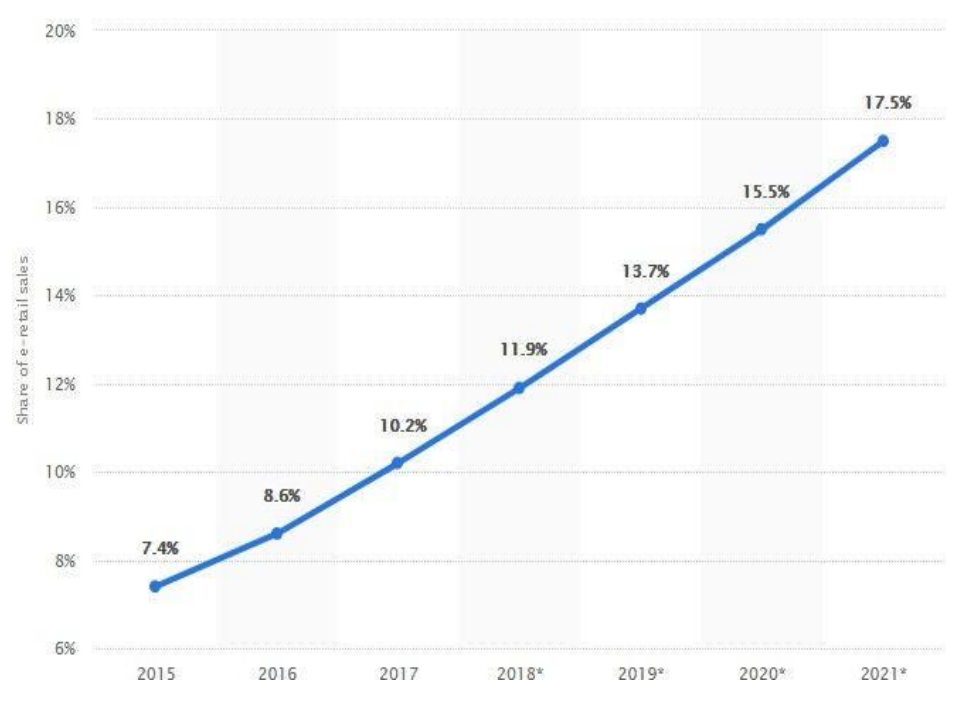

Gambar 1. Data Penjualan E-Commerce secara Global Sumber : Statista.com

Kebanyakan transaksi penjualan yang ada dilakukan melalui perangkat pribadi seperti smartphone dan tablet, jadi secara tidak langsung juga dapat 
meningkatkan jumlah transaksi pertukaran data dan informasi yang tersedia, berdasarkan data dari Global web index kuartal ke 2 yang dikutip oleh digital market asia, pada rentang umur 16-64 tahun yang melakukan transaksi online lewat perangkat elektronik dengan jumlah sampel responden pengguna internet sebanyak 72.529 dikawasan asia sendiri penjualan ini di dominasi oleh negara China, tapi Indonesia sendiri berada pada peringkat ke 5 sehingga bisa ditarik kesimpulan bahwa pasar penjualan secara online di Indonesia ini memiliki prospek yang cukup baik.

Tabel 1. Top 10 Online Commerce Market

\begin{tabular}{|c|c|}
\hline Negara & Rata-Rata Pengguna Internet \\
\hline Cina & $\mathbf{8 3 \%}$ \\
\hline Korea Selatan & $\mathbf{8 3 \%}$ \\
\hline Inggris & $\mathbf{8 2 \%}$ \\
\hline Jerman & $\mathbf{8 1 \%}$ \\
\hline Indonesia & $\mathbf{7 9 \%}$ \\
\hline
\end{tabular}

Sumber : digitalmarket.asia, diolah peneliti

Mengingat besarnya potensi pasar yang akan diperoleh maka Kementrian Komunikasi dan Informatika Republik Indonesia (Kominfo) melakukan pengadaan dan pembangunan infrastruktur untuk layanan komunikasi yang lebih baik, beberapa langkah yang dilakukan Kominfo adalah dengan :

\section{Mengadakan Program Palapa Ring}

Palapa Ring menghubungan seluruh nusantara yang bertujuan memastikan masyarakat didaerah terdepan, tertinggal dan terluar (3T) bisa menikmati layanan telekomunikasi yang lebih baik, dengan target 514 kabupaten/kota terlayani di tahun 2018, dari pencapaian 400 kabupaten/kota saat ini.

\section{Refarming $4 \mathrm{G}$}

Penataan frekuensi telekomunikasi refarming 4G dan digitalisasi penyiaran memastikan frekuensi telekomunikasi dan siaran dikelola efisien dan bermanfaat untuk semua masyarakat. Dengan target tahun 2019, sebanyak 514 kabupaten/kota terlayani jaringan 4G/LTE. 


\section{Digitalisasi Penyiaran}

Hasil penataan frekuensi dan migrasi penyiaran dari analog ke digital akan menjadikan layanan telekomunikasi dan informasi lebih optimal terlebih di daerah terdepan, tertinggal dan terluar (3T)

Proses pertukaran data dan informasi yang cepat dan instan ini pula yang mengubah pola perilaku konsumen era moderen dengan lebih mengandalkan web media sosial untuk memperoleh informasi dan review dari produk yang diinginkan, hal ini dijelaskan dari data yang diluncurkan oleh Tetra Pak Index tahun 2017, menunjukkan ada sekitar 132 juta pengguna internet di Indonesia. Sementara hampir setengahnya adalah penggila media sosial, atau berkisar di angka 40\%, dimana angka ini mengalami kenaikan dari tahun 2016 dimana kenaikan penguna internet di Indonesia berkisar 51\% atau sekitar 45 juta pengguna, diikuti dengan pertumbuhan sebesar $34 \%$ pengguna aktif media sosial. Sementara pengguna yang mengakses sosial media melalui perangkat mobile pribadi berada di angka $39 \%$.

Salah satu faktor yang mempengaruhi keberhasilan pemasaran melalui media sosial adalah dengan menggunakan influencer marketing secara definisi influencer marketing adalah sebuah cara dengan menunjuk orang atau figur yang dianggap memiliki pengaruh diantara masyarakat atau segmen target konsumen yang akan dituju dan dirasa bisa menjadi sasaran promosi dari merek tersebut. Penggunaan metode ini akan membuat sang influencer berperan sebagai pembeli atau pengguna suatu merek yang mampu merepresentasikan tentang hal- hal positif yang dimiliki merek sehingga dapat meningkatkan tingkat penjualan dari merek produk tersebut. berdasarkan data dan definisi yang ada ini maka peneliti ingin mengetahui pola dari influncer ini sebagai salah satu strategi pemasaran digital di era moderen.

\section{LANDASAN TEORI}

\section{Definisi Pemasaran}

Definisi pemasaran menurut Kamus Besar Bahasa Indonesia (KBBI) adalah sebuah proses, cara, perbuatan untuk memasarkan suatu barang dagangan, sementara definisi dari strategi pemasaran adalah rencana untuk memperbesar pengaruh terhadap pasar, baik dalam jangka pendek maupun dalam jangka panjang, yang didasarkan pada riset pasar, penilaian, perencanaan produk, promosi dan perencanaan penjualan, serta distribusi. Sedangkan definisi pemasaran menurut Kotler (2018) adalah Proses di mana perusahaan melibatkan pelanggan, membangun hubungan baik dengan pelanggan, dan menciptakan nilai untuk pelanggan, sehingga dapat mendapatkan nilai / umpan balik yang baik dari pelanggan dalam rangka untuk meningkatkan profit dan ekuitas pelanggan. Salah satu unsur dari pemasaran adalah marketing mix yang menjadi variabel dalam 
pemasaran dalam rangka untuk memenuhi target penjualan. Unsur dalam marketing mix dikenal dengan nama $7 \mathrm{p}$ yaitu : product, price, place, promotion, physical evidence, process dan people

Jadi definisi dari pemasaran secara umum adalah kegiatan memanfaatkan variabel-variabel penjualan untuk mendatangkan konsumen, meningkatkan penjualan, dan menjaga hubungan baik dengan konsumen sehingga kegiatan transaksi yang terjadi dapat dilakukan secara terus menerus dan berkesinambungan.

\section{E-Marketing}

E-Marketing (Electronic Marketing) menurut Tjiptono (2016) adalah proses strategik, mengembangkan, mendistribusikan, mempromosikan, dan menetapkan harga barang dan jasa kepada pasar sasaran melalui internet atau alatalat digital seperti smartphone.pada saat ini e-marketing menjadi salah satu pilihan made of entry yang dinilai efektif dan efisien, terutama untuk produk digital, seperti perangkat lunak, video, musik dan sejenisnya.

Pertumbuhan pengguna internet di Indonesia pada tahun 2017 menurut survey dari Asosiasi Pengguna Jasa Internet Indonesia (APJII) tahun 2017 seperti pada gambar 2. mencapai 143.26 Juta Pengguna yang berarti mengalami kenaikan dari tahun 2016 yang mencapai 132,7 Juta pengguna dari jumlah total populasi penduduk indonesia yang berada pada angka 262 juta orang. Hal ini bahwa penetrasi pertumbuhan pemakai internet di Indonesia pada tahun 2017 mencapai $54.68 \%$ dibandingkan pada tahun 2016 yang sebesar 51.03\%.

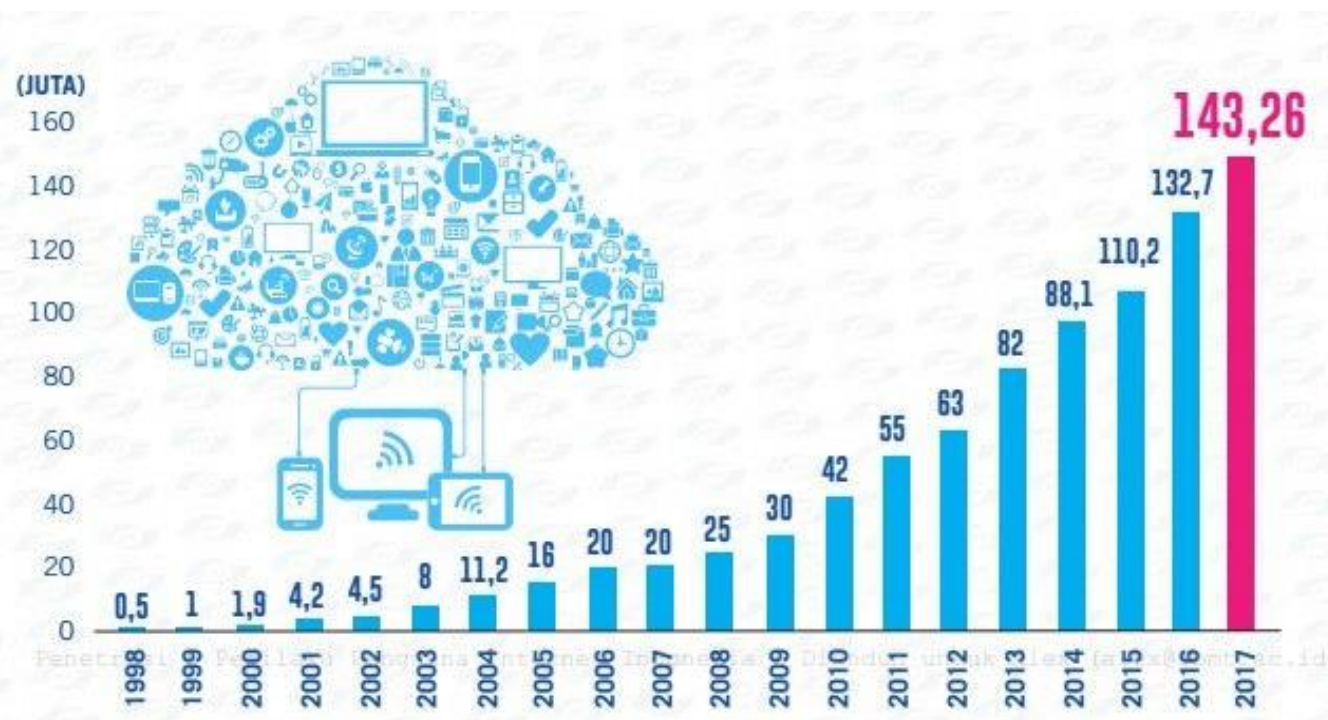

Gambar 2. Pertumbuhan Pengguna Internet Indonesia Sumber : APJII 
Berdasarkan data yang ada ini menunjukkan pemsaran yang dilakukan melalui metode pemasaran secara digital diyakini dapat mendatangkan keuntungan yang lebih baik daripada menggunakan metode pemasaran secara manual, tetapi tetap tidak bisa menghilangkan unsur pemasaran secara manual, karena bagi sebagian masyarakat pemasaran melalui teknologi digital masih dianggap rawan akan keamanan.

\section{Media Sosial}

Definisi Media Sosial menurut Tjiptono (2016) adalah teknologi berbasis internet yang menfasilitasi percakapan. Perbedaan dengan aplikasi web tradisional adalah pada platform berupa content creation, content upload, networking, conversing, media sharing dan bookmarking, secara garis besar media sosial menjadi lima kategori seperti pada tabel 2. yaitu :

Tabel 2. Top 10 Online Commerce Market

\begin{tabular}{|c|c|c|}
\hline $\begin{array}{l}\text { Kategori Media } \\
\text { Sosial }\end{array}$ & Penjelasan & Contoh Situs \\
\hline Egocentric Sites & $\begin{array}{c}\text { Memungkingkan pengguna untuk } \\
\text { membuat profil diri di platform virtual, } \\
\text { yang kemudian memfasilitasi konstruksi } \\
\text { dan koneksi identitas. }\end{array}$ & $\begin{array}{c}\text { Facebook, Myspace, } \\
\text { Bebo }\end{array}$ \\
\hline Community Sites & $\begin{array}{l}\text { Mengimitasi komunitas dunia nyata, } \\
\text { sehingga memungkinkan kelompok- } \\
\text { kelompok terbentuk. }\end{array}$ & $\begin{array}{l}\text { Bigwavedave, } \\
\text { Blackplanet, } \\
\text { Dogster }\end{array}$ \\
\hline Opportunistic Sites & $\begin{array}{c}\text { Memungkingkan terbentuknya } \\
\text { bermacam-macam organisasi sosial para } \\
\text { pengguna dan memfasilitasi koneksi } \\
\text { bisnis }\end{array}$ & $\begin{array}{l}\text { LinkedIn, } \\
\text { Academic.Edu, } \\
\text { Alibaba }\end{array}$ \\
\hline Passion-Centric Sites & $\begin{array}{l}\text { Memungkinkan pengguna untuk } \\
\text { berhubungan berdasarkan minat dan hobi }\end{array}$ & $\begin{array}{l}\text { Thesamba, } \\
\text { chatterbird, } \\
\text { germancarforum }\end{array}$ \\
\hline Media Sharing Sites & $\begin{array}{c}\text { Memungkinkan pengguna untuk saling } \\
\text { berbagi media, seperti gambar, audio dan } \\
\text { video }\end{array}$ & $\begin{array}{l}\text { Flickr, youtube, } \\
\text { slideshare }\end{array}$ \\
\hline
\end{tabular}

Sumber : Tjiptono, 2016, diolah peneliti

Salah satu rekayasa pemasaran dalam memanfaatkan media sosial supaya lebih efektif adalah dengan menggunakan influencer marketing, influencer yang dimaksud adalah seseorang atau public figur yang ada dalam media sosial yang memiliki jumlah follower yang banyak atau signifikan dan apa yang mereka 
sampaikan pada media sosial itu dapat mempengaruhi atau merespon perilaku dari pengikutnya.

\section{METODE PENELITIAN}

Pendekatan yang digunakan pada penelitian ini adalah dengan menggunakan pendekatan literature review. Dalam melakukan pengumpulan data, penulis mengumpulkan data dan informasi yang berkaitan dengan sistem pemasaran dan pemasaran digital melalui data-data pendukung yang bersumber dari jurnal penelitian baik nasional maupun internasional, buku-buku penunjang, surat kabar, dan majalah.

literature review seperti yang dijelaskan Cooper dalam Creswell (2010) mempunyai beberapa tujuan yaitu menginformasikan kepada pembaca hasilhasil penelitian lain yang berkaitan erat dengan penelitian yang dilakukan saat itu, menghubungkan penelitian dengan literatur-literatur yang ada, dan mengisi celah dalam penelitian-penelitian sebelumnya, literature review berisi ulasan, rangkuman, dan pemikiran penulis tentang beberapa sumber pustaka (artikel, buku, slide, informasi dari internet, data gambar dan grafik dan lain lain) tentang topik yang dibahas. Studi literatur ini mempunyai tujuan untuk mengetahui pengaruh dan peranan influencer marketing terhadap salah satu dari strategi pemasaran digital dengan memanfaatkan media sosial.

\section{PEMBAHASAN}

Penggunaan media sosial tidak cuma dipandang sebagai fasilitas untuk aktualisasi diri namun bisa berkembang kearah dunia bisnis salah satunya adalah media sosial dapat menjadi sarana marketing dan juga dapat digunakan sebagai penunjang untuk mendapatkan review atau informasi mengenai suatu produk barang atau jasa yang akan atau sedang dipasarkan sehingga dapat menarik minat atau respon dari konsumen dalam memutuskan untuk melakukan transaksi pembelian.

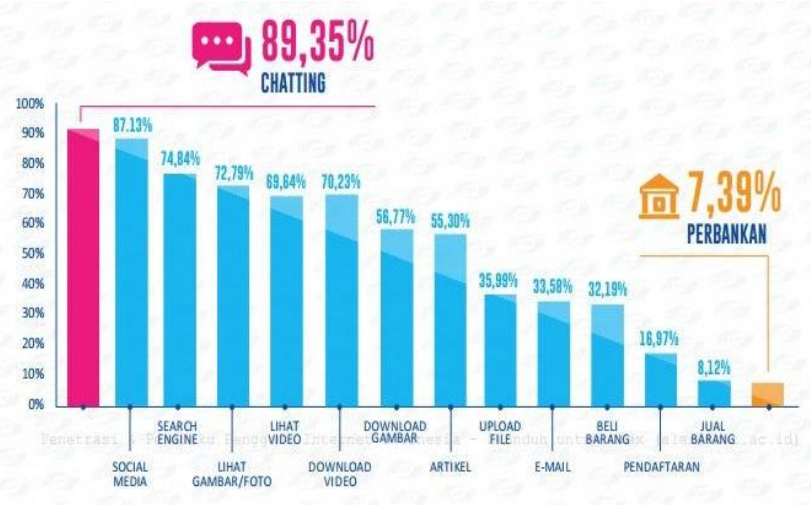

Gambar 3. Layanan yang diakses pengguna Internet Indonesia Sumber : APJII 
Data pada gambar 3. Menunjukkan bahwa tingkat layanan sosial media adalah termasuk layanan yang paling sering diakses pengguna internet di Indonesia dengan $87.13 \%$ pengguna Internet Indonesia dengan berada pada urutan kedua dibawah dari chating yang memiliki presentase sebesar $89.35 \%$, hal ini memberikan kesimpulan bahwa kegiatan internet masyarakat Indonesia didominasi oleh akses melalui chatting dan akses media sosial. Hal inilah yang menyebabkan pemasaran yang dilakukan melalui sosial media dianggap mampu dan berpotensi besar untuk meningkatkan penjualan terhadap produk atau jasa yang dipasarkan.

Influencer Marketing dipandang sebagai salah satu strategi terbaik untuk mendatangkan calon konsumen pada saat melakukan pemasaran menggunakan media sosial dengan memanfaatkan massa yang dimiliki oleh seorang influencer, seorang influncer dapat menciptakan brand image produk yang lebih baik dan dengan biaya yang lebih terjangkau dibandingkan menggunakan brand endorser artis atau figur publik yang sudah berada kalangan artis papan atas. Seorang influencer secara umum biasanya dipilih berdasarkan kemampuan, keahlian, tingkat popularitas, maupun reputasi yang dimilikinya. Dengan menggunakan cara ini suatu perusahaan atau merek tertentu diharapkan akan lebih loyal kepada sang influencer yaitu dengan membangun hubungan yang lebih dalam dan tidak hanya sekedar sebatas menjelaskan tentang produk itu saja namun lebih kepada informasi juga penunjang khusus yang diperoleh terhadap produk baru serta proses dibelakang layar dari merek yang akan dipromosikan.

Hal yang perlu diperhatikan saat memilih influencer tentu kembali kepada konsep Segmentasi, sasaran (targetting) dan penempatan (positioning) dari target konsumen yang diinginkan karena hal ini akan mempengaruhi terhadap jumlah pengikut dan tingkat keterlibatan platform yang akan digunakan, platform yang dimaksud adalah terkadang seorang influencer dapat membuat komunitaskomunitas yang bisa mengasih kesan terhadap produk yang mau dipasarkan, pada beberapa kasus terkadang influencer dengan jumlah pengikut yang kecil namun memiliki keterlibatan yang tinggi dapat lebih efektif dalam mempengaruhi tingkat penjualan produk kepada konsumen.

Posisi popularitas dari sosial media pun turut mempengaruhi tingkat popularitas dari seorang influencer tersebut dan menambah jumlah influencer tersebut, maka secara tidak langsung juga akan menjangkau tingkat konsumen yang lebih luas yang menyesuaikan dengan media sosial tersebut, di Indonesia sendiri seperti data pada katadata.co.id tahun 2018 menyebutkan pada 2017 pengguna internet di Indonesia pada rentang usia 16-64 tahun, menyebutkan media sosial yang secara aktif dipakai oleh masyarakat Indonesia adalah Youtube menempati peringkat pertama dengan persentase penggunaan sebesar $43 \%$, dan pada peringkat ke dua Facebook dengan persentase penggunaan sebesar $41 \%$, dan pada posisi ketiga adalah Whatsapp dengan persentase 
penggunaan sebesar $40 \%$ seperti pada gambar 4.

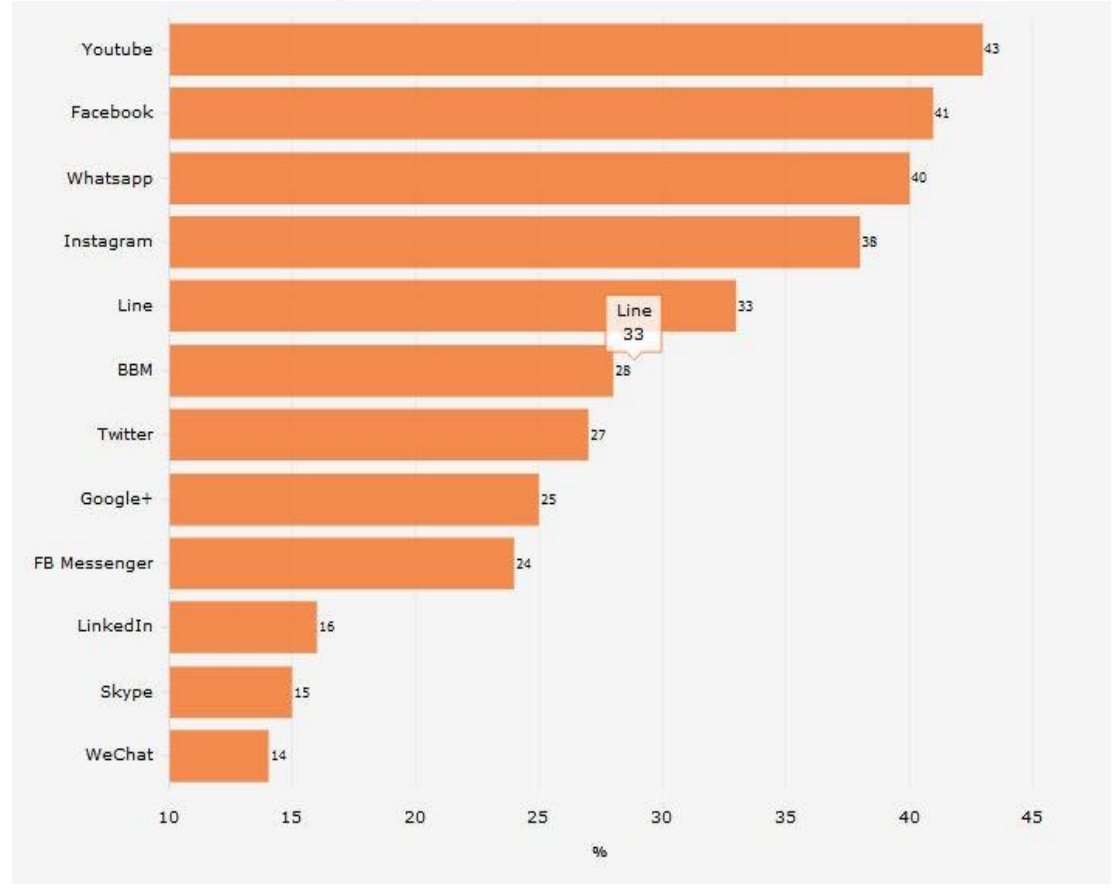

Gambar 4. Layanan yang diakses pengguna Internet Indonesia Sumber : Katadata

Seorang pemasar dalam memanfaatkan jasa influencer harus membuat kerjasama kontrak untuk menghindari terjadinya konflik di kemudian hari, dalam pembayaran tidak selalu influencer harus dibayar dengan menggunakan nominal uang, tetapi bisa dengan menggunakan promo atau fasilitas-fasilitas yang dimiliki oleh brand tersebut sehingga bisa dimanfaatkan untuk dijadikan sebuah pengalaman yang bisa diposting kembali pada platform mereka.

\section{KESIMPULAN}

Berdasarkan hasil dan pembahasan yang telah dilakukan maka dapat ditarik kesimpulan antara lain :

1. Potensi pemasaran era moderen didominasi oleh pemasaran melalui media sosial yang diakses melalui perangkat pribadi.

2. Influencer Marketing merupakan salah satu strategi pemasaran dengan memanfaatkan media sosial.

3. Menggunakan Influencer Marketing dapat secara signifikan meminimalkan pengeluaran biaya yang digunakan untuk promosi.

4. Penerapan Influencer Marketing sangat cocok diimplementasikan untuk meningkatkan citra merek (Brand Image) secara efektif dan meningkatkan Brand Awareness konsumen terhadap merek tersebut. 


\section{DAFTAR PUSTAKA}

Creswell John W., 2010, Research Design : Qualitative, Quantitative, and Mixed Methods Approaches, 3th, terjemahan Achmad Fawaid, Yogyakarta.

Kotler Philip., 2018 Principles of Marketing : Global Edition, 17th. United Kingdom : Pearson.

Tjiptono, Fandy. 2016. Pemasaran : Esensi dan Aplikasi. Yogyakarta : Andi.

Kamus Besar Bahasa Indonesia. 2005. Cetakan pertama edisi ketiga. Jakarta : Balai Pustaka.

Survei internet APJII 2017 (dapat diakses di https://apjii.or.id, diakses pada 21 Maret 2018

https://databoks.katadata.co.id/datapublish/2018/02/01/media-sosial-apa-yangpaling-sering-digunakan-masyarakat-indonesia, diakses pada 21 Maret 2018

https://inet.detik.com/cyberlife/d-3659956/132-juta-pengguna-internet-indonesia40-penggila-medsos, diakses 21 Maret 2018

https://kominfo.go.id/content/detail/8481/infrastruktur-telekomunikasi-dukungdaya-saing-indonesia/0/infografis, diakses 21 Maret 2018

http://www.digitalmarket.asia/data-pick-day-china-leads-online-shopping/, diakses 20 Maret 2018

https://www.statista.com/statistics/534123/e-commerce-share-of-retail-salesworldwide/, diakses 20 Maret 2018 